\title{
Response Spectrum Analysis for Regular Multistory Structure in Seismic Zone III
}

\author{
S. R. Kangle ${ }^{1}$ \\ ${ }^{1}$ M.E Civil-Structure Student, \\ Department of Civil Engineering, \\ JSPM's Rajarshi Shahu College of Engineering \\ Tathawade, Pune-411033, India
}

\author{
D. S. Yerudkar ${ }^{2}$ \\ ${ }^{2}$ Associate Professor, \\ Department of Civil Engineering, \\ JSPM's Rajarshi Shahu College of Engineering \\ Tathawade, Pune-411033, India
}

\begin{abstract}
An RCC framed structure is basically an assembly of slabs, beams, columns and foundation interconnected to each other as a unit. The load transfer, in such a structure takes place from the slabs to the beams, from the beams to the columns and then to the lower columns and finally to the foundation which in turn transfers it to the soil. The results of analysis are used to verify the structure fitness for use. Computer software's are also being used for the calculation of forces, bending moment, stress, strain \& deformation or deflection for a complex structural system. The principle objective of this project is "The Comparative Study on Analysis Results of Multistoried Commercial Building $(\mathbf{G + 1 5})$ by STAADPRO and ETABS".STAADPRO is one of the leading software's for the design of structures. In this project we had analyzed the $\mathrm{G}+15$ building through response spectrum analysis to develop the economic design. ETABS is also leading design software in present days used by many structural designers. Here $I$ have also analyzed the same structure using ETABS software for the design.IS: 1893 (Part I) for seismic design is utilized to perform the dynamic analysis. The results were observed that the multistoried buildings are stiff for earthquake excitation as modal participation factor is found to be more than $\mathbf{7 5}$ percent.
\end{abstract}

Keywords:-STAADPRO, ETABS, Response Spectrum Analysis

\section{INTRODUCTION}

Earthquake causes the random ground motions in all directions, radiating from the epicenter. These ground motions causes structure to vibrate and induces inertia forces in them. For the structure to perform better during the earthquakes, it must be analyzed and designed as per the Indian seismic code IS 1893 (Part 1) 2002. In the past, several major earthquakes have exposed the shortcomings in buildings, which had caused them to damage or collapse. It has been found that regular shaped buildings perform better during earthquakes. Earthquakes causes ground to vibrate and structures supported on ground are subjected to this motion. Thus the dynamic loading on the structure during an earthquake is not an external loading, but due to motion of support. The building can be designed to resist earthquake with certain amount of damage, but without causing the collapse and affecting the livelihood. The response spectrum represents an interaction between ground acceleration and the structural system, by envelope of several different ground motion records. For the purpose of the seismic analysis the design spectrum given in fig.2 of IS 1893 (Part 1): 2002 is used. Response spectrum analysis of the building model is performed using STAADPRO \& ETABS. The lateral loads generated by STAADPRO correspond to the seismic zone III and 5\% damped response spectrum given in IS 1893 (Part1): 2002.

\section{A. Objectives of the Present Study}

1. To determine dynamic response of multi-story building for earthquake load.

2.To study story displacement, story shear, story drift using response spectrum analysis for a regular multistory building.

3.To study response spectrum analysis of regular multistory building using computer programs (STAADPRO,ETABS)

\section{B. Response Spectrum Analysis}

The response spectrum method (RSM) was introduced in 1932 in the doctoral dissertation of Maurice Anthony Biot at Caltech. It is an approach to finding earthquake response of structures using waves and vibration mode shapes. The concept of the "response spectrum" was applied in design requirements in the mid-20th century in building codes of various countries. The computational advantages in using the response spectrum method of seismic analysis are the prediction of displacements and member forces in structural systems. The method involves the calculation of only the maximum values of the displacements and member forces in each mode using smooth design spectra that are the average of several earthquake motions.

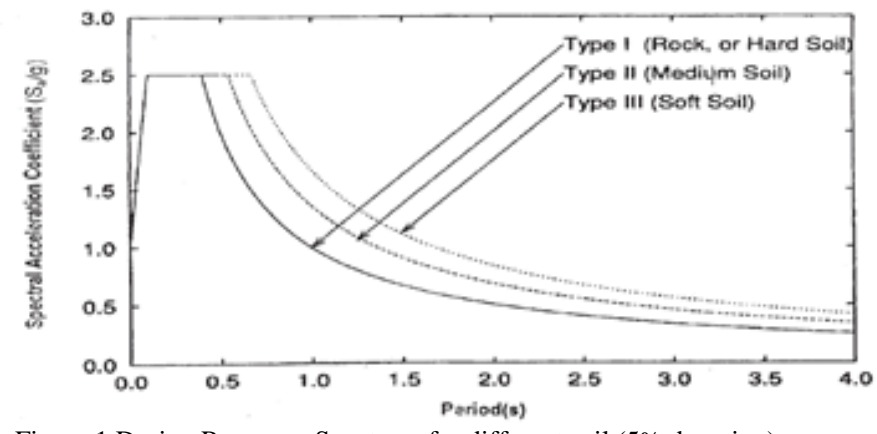

Figure.1 Design Response Spectrum for different soil (5\% damping)

\section{Necessity of seismic zoning in India}

Seismic zonation is a process, which provided information about any decision making for urban regional planning or for earthquake design in earthquake areas. In principle, seismic zoning map is the main source of zoning, which is 
displaying quantities related to the expected frequency and intensity of shaking caused by earthquakes. The task of seismic zoning is multidisciplinary and involves the best of inputs from geologists, geotechnical, seismologists, earthquake and structural engineers .The rapid urbanization due to population outburst, coming up of mega cities in potential seismic zones is the main reason of the seismic hazard in India.

\section{IS 1893:2002 provisions for zones.}

According to IS 1893 code, seismic zonation map of a country is a guide to the seismic status of a region and its susceptibility to earthquakes. India has been divided into four zones with respect to severity of earthquakes Zone factor ( $\mathrm{Z}$ ) given in table 4.1, is for the maximum considered earthquake (MCE) and service life of a structure in a zone. For design horizontal seismic coefficient

$\mathbf{A h}=(\mathbf{Z} / \mathbf{2})(\mathbf{S a} / \mathbf{g})(\mathbf{I} / \mathbf{R})$ factor 2 in the denominator of $\mathrm{Z}$ is used so as to reduce the Maximum Considered Earthquake zone factor to the factor for design basis earthquake (DBE).

For any structure with $\mathrm{t}<0.1 \mathrm{~s}$, the value of $\mathrm{Ah}$ will not be taken less than $Z / 2$ whatever be the value of I/R. Table no 1 Zone Factor Z (Clause 6.4)

\begin{tabular}{|c|c|c|c|c|}
\hline $\begin{array}{c}\text { Seismic } \\
\text { Zone }\end{array}$ & II & III & IV & $\mathrm{V}$ \\
\hline Intensity & Low & Moderate & Severe & $\begin{array}{c}\text { Very } \\
\text { Severe }\end{array}$ \\
\hline $\mathrm{Z}$ & 0.10 & 0.16 & 0.24 & 0.36 \\
\hline
\end{tabular}

\section{METHODOLOGY}

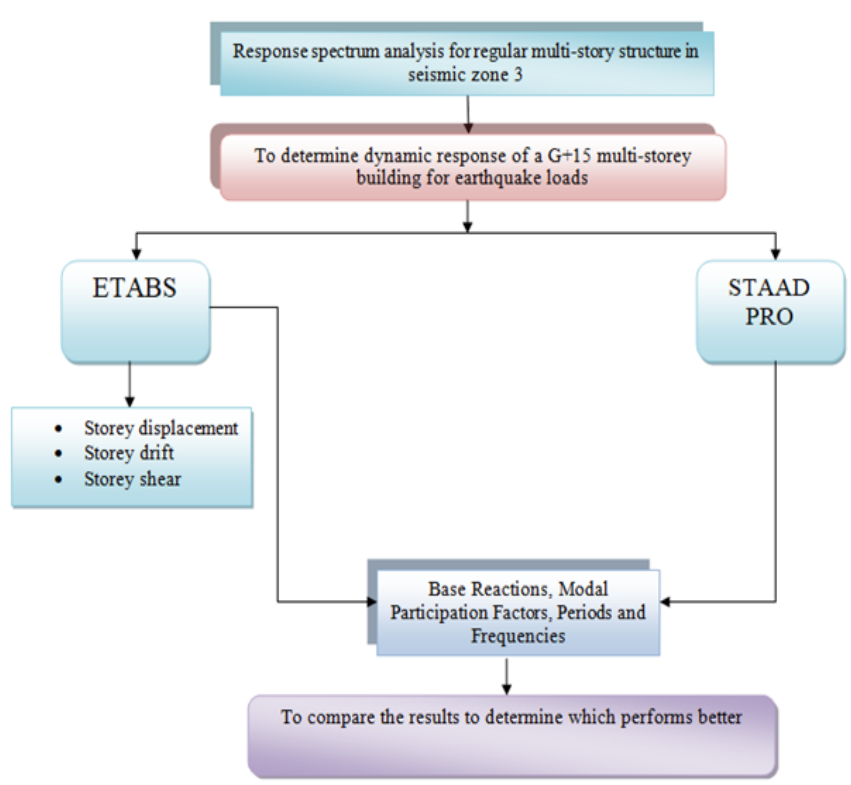

III. PROBLEM STATEMENT

Reinforced concrete moment resisting frame building of different story heights are considered. The bottom story height is kept $3 \mathrm{~m}$ and a typical height of $3 \mathrm{~m}$ is kept for the entire story in the building. The aim of the study is to find the difference of base reactions, modal participation factors and periods and frequencies using ETABS and STAADPRO.
Table no 2 Detail data of building studied

\begin{tabular}{|c|c|c|c|}
\hline Sr no. & \multicolumn{3}{|c|}{ Design data for the building } \\
\hline I & \multicolumn{3}{|c|}{ Detail of building } \\
\hline a) & \multicolumn{2}{|c|}{ Structure } & OMRF \\
\hline b) & \multicolumn{2}{|c|}{ Number of story } & $\mathrm{G}+15$ \\
\hline \multirow[t]{2}{*}{ c) } & Story height & Ground story & $4.00 \mathrm{~m}$ \\
\hline & & Upper story & $3.00 \mathrm{~m}$ \\
\hline d) & \multicolumn{2}{|c|}{ Type of building } & Commercial \\
\hline e) & \multicolumn{2}{|c|}{ Seismic zone } & III \\
\hline II & \multicolumn{3}{|c|}{ Material properties } \\
\hline a) & \multicolumn{2}{|c|}{ Grade of concrete } & M25 \& M30 \\
\hline b) & \multicolumn{2}{|c|}{ Grade of steel } & Fe 500 \\
\hline c) & \multicolumn{2}{|c|}{ Density of reinforcement concrete } & $25 \mathrm{KN} / \mathrm{M}^{3}$ \\
\hline d) & \multicolumn{2}{|c|}{ Density of steel } & $78.5 \mathrm{KN} / \mathrm{M}^{3}$ \\
\hline III & \multicolumn{3}{|c|}{ Member Properties } \\
\hline a) & \multicolumn{3}{|c|}{ Beam } \\
\hline i) & \multicolumn{2}{|c|}{ Grade } & M25 \\
\hline ii) & \multicolumn{2}{|c|}{ Size (for all stories) } & $0.45 \mathrm{~m} \times 0.23 \mathrm{~m}$ \\
\hline b) & \multicolumn{3}{|c|}{ Column } \\
\hline i) & \multicolumn{2}{|l|}{ Grade } & $\mathrm{M} 30$ \\
\hline ii) & \multicolumn{2}{|l|}{ Sizes } & $\begin{array}{l}0.65 \mathrm{~m} \times 0.23 \mathrm{~m} \\
\& 0.75 \mathrm{~m} \times 0.75 \mathrm{~m}\end{array}$ \\
\hline c) & \multicolumn{3}{|l|}{ Slab } \\
\hline i) & \multicolumn{2}{|l|}{ Grade } & M25 \\
\hline ii) & \multicolumn{2}{|c|}{ Thickness } & $125 \mathrm{~mm}$ \\
\hline IV & \multicolumn{3}{|c|}{ Types of loads } \\
\hline i) & \multicolumn{2}{|c|}{ Dead } & $2.5 \mathrm{KN} / \mathrm{M}^{2}$ \\
\hline ii) & \multicolumn{2}{|l|}{ Live } & $3.5 \mathrm{KN} / \mathrm{M}^{2}$ \\
\hline $\mathrm{V}$ & \multicolumn{3}{|c|}{ Seismic properties } \\
\hline i) & \multicolumn{2}{|c|}{ Zone factor $(Z)$} & 0.16 \\
\hline ii) & \multicolumn{2}{|c|}{ Importance factor (I) } & 1 \\
\hline iii) & \multicolumn{2}{|c|}{ Response reduction factor (I) } & 5 \\
\hline iv) & \multicolumn{2}{|c|}{ Soil type } & II \\
\hline v) & \multicolumn{2}{|c|}{ Damping factor } & 0.050 \\
\hline
\end{tabular}

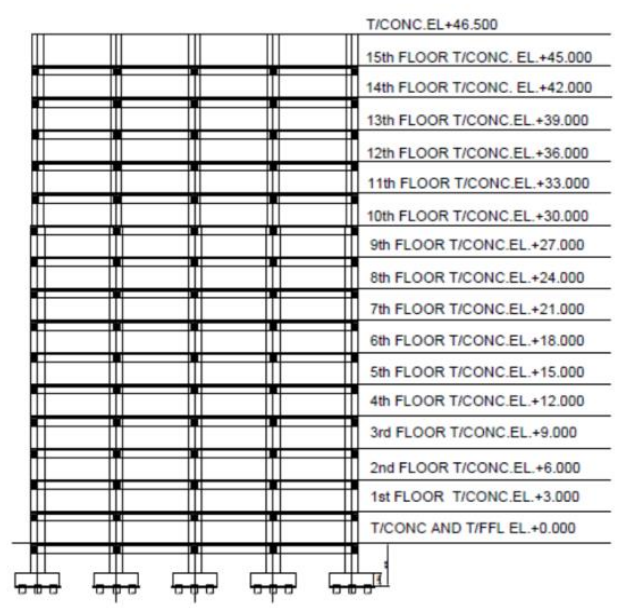

Figure.2 A typical G+15 story plan

\section{MODELLING AND ANALYSIS}

The ETABS \& STAADPRO software is used for modeling as well as analysis of the structure. The symmetrical plan of reinforced concrete structure having 15 story is considered. First the Earthquake loads as per IS1893-2002, Part-1 are applied for structure located in zone III. And dynamic analyses i.e. Response spectrum method is carried out for 5\% damping and scale factor considered as per IS code in both $\mathrm{X}$ and $\mathrm{Y}$ directions. Assuming that material property is linear static and Response spectrum analysis is performed. 


\section{Loadings and material properties}

M25 grade of concrete and Fe 500 grade of Steel are used for all slabs and beams of the building whereas M30 is used for columns with same grade of Steel. Elastic material properties of these materials are taken as per IS 456-2000. The short-term modulus of elasticity $(E c)$ of concrete is taken as

$$
\boldsymbol{E} \boldsymbol{c}=5000 \sqrt{ } f c k \mathrm{Mpa}
$$

$\boldsymbol{f} \boldsymbol{c k}=$ characteristic compressive strength of concrete cube For the Steel rebar with stress and modulus of elasticity is taken as per IS 456-2000.

While applying the loads to the structure we consider only the external loads which are actually acting on the members neglecting its self-weight because ETABS 2018 \& STAADPRO automatically take the members selfweight.

The Seismic loads EQ-x and EQ-y are given in Load patterns directly using Code IS1893:2002. Also the Wind loads wind- $x$ and wind-y are IS875:2015 by ETABS 2018 given using code IS875:2015 by ETABS 2018

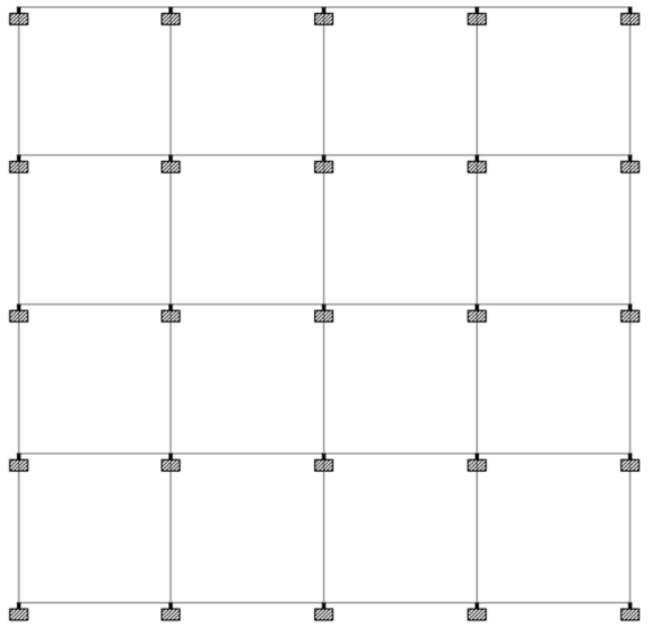

Figure 4 Top View

Elevation, Top view and 3D Model of the building

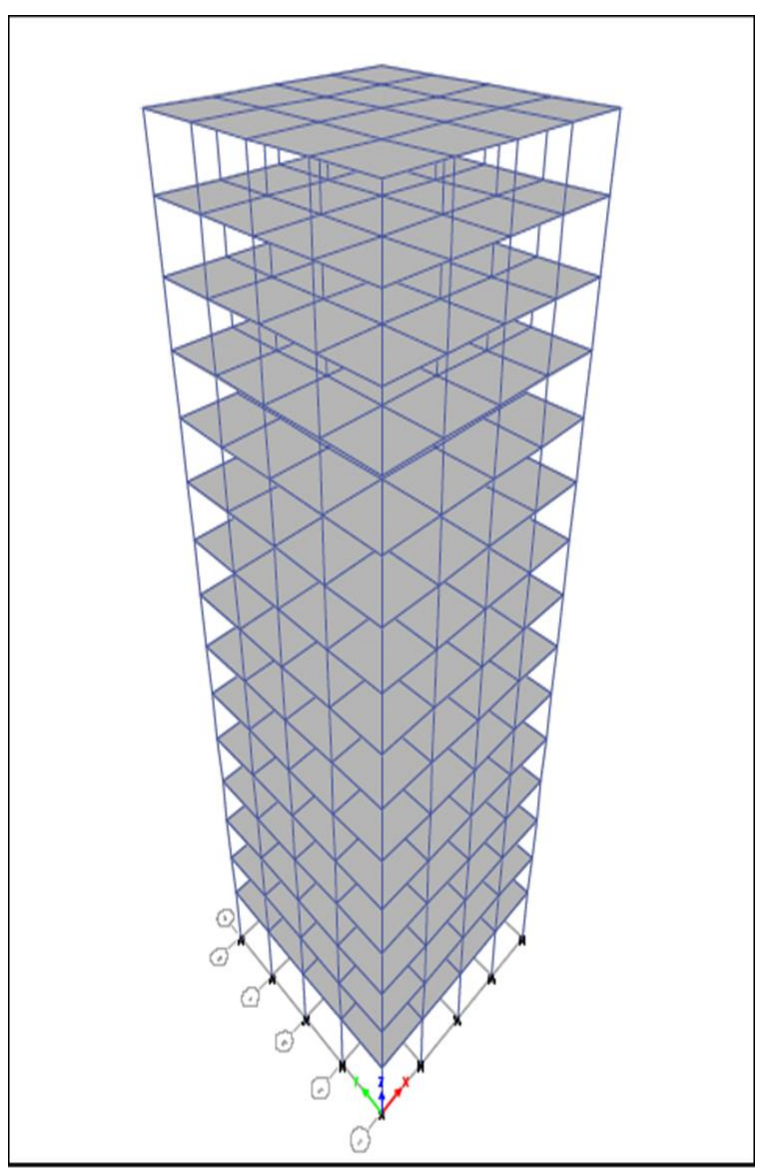

STAADPRO
Figure 3 3D model of building

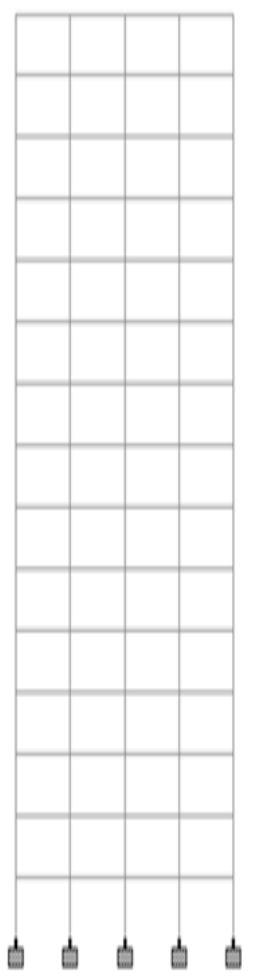

Figure 5 Elevation of a G+15 Building using 


\section{RESULTS AND DISCUSSION}

\section{A. Base Reactions.}

Table no 3 base reactions obtained from STAADPRO AND ETABS

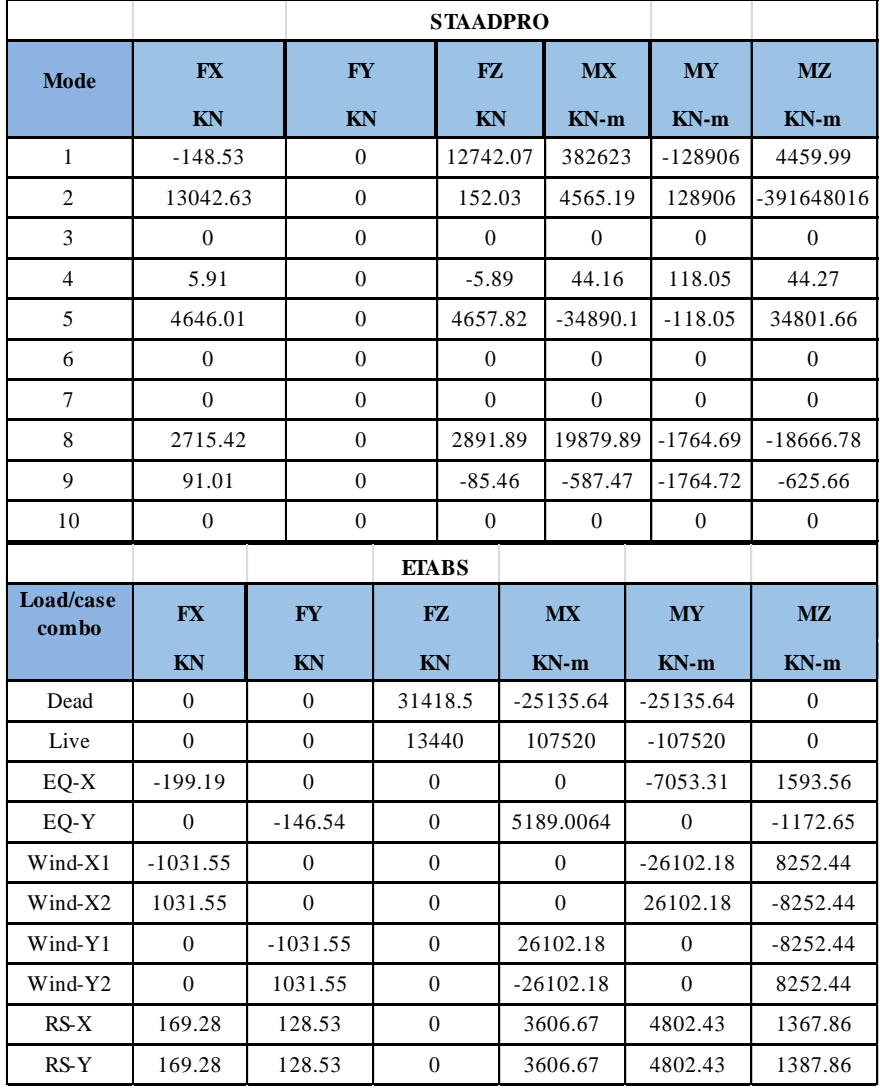

\section{B. Modal Participation Factor}

Table no 4 modal participation factors obtained from STAADPRO and ETABS

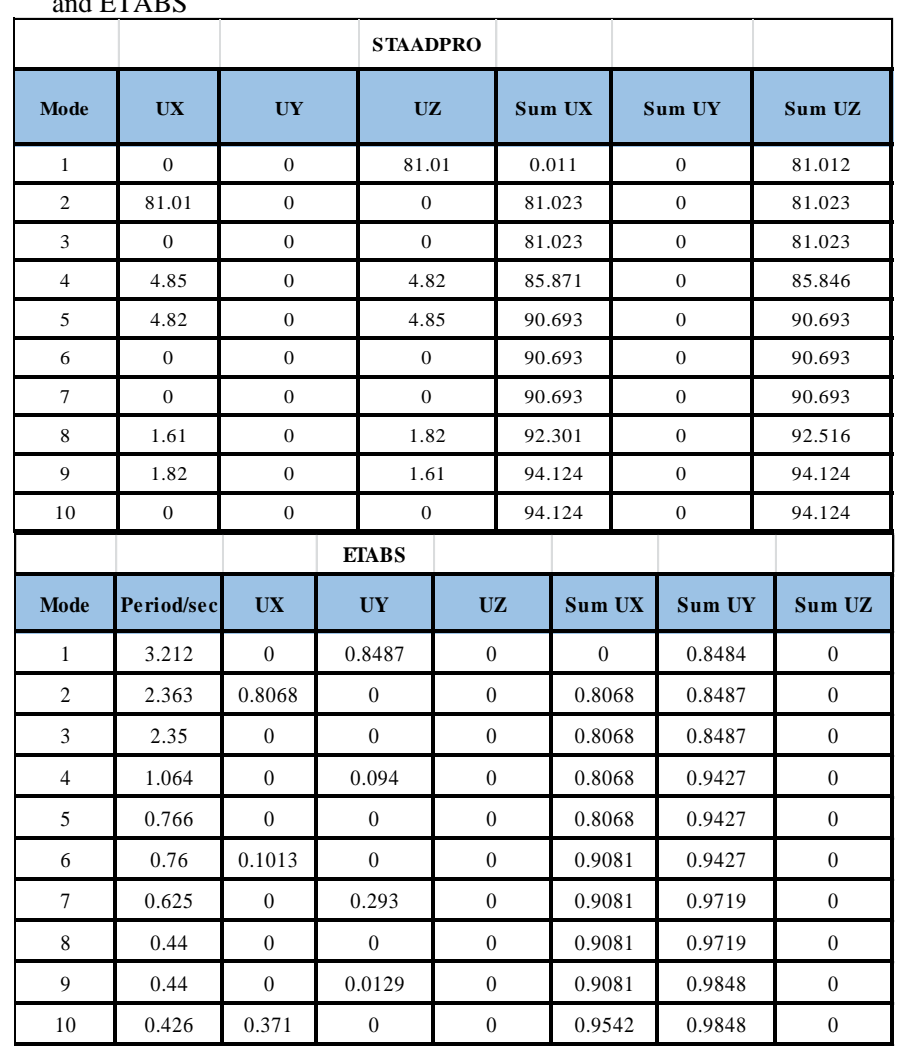

\section{Periods and Frequencies.}

Table no 5 Periods and Frequencies obtained from STAADPRO and ETABS

\begin{tabular}{|c|c|c|}
\hline & STAADPRO & \\
\hline Mode & Period & Frequency \\
\hline 1 & 5.834 & 0.171 \\
\hline 2 & 5.834 & 0.171 \\
\hline 3 & 5.834 & 0.193 \\
\hline 4 & 5.834 & 0.518 \\
\hline 5 & 5.834 & 0.518 \\
\hline 6 & 5.834 & 0.582 \\
\hline 7 & 5.834 & 0.85 \\
\hline 8 & 5.834 & 0.881 \\
\hline 9 & 5.834 & 0.881 \\
\hline \multirow[t]{2}{*}{10} & 5.834 & 0.982 \\
\hline & ETABS & \\
\hline Mode & Period & Freque ncy \\
\hline 1 & 3.212 & 0.311 \\
\hline 2 & 2.363 & 0.423 \\
\hline 3 & 2.35 & 0.426 \\
\hline 4 & 1.064 & 0.94 \\
\hline 5 & 0.766 & 1.306 \\
\hline 6 & 0.76 & 1.316 \\
\hline 7 & 0.625 & 1.6 \\
\hline 8 & 0.44 & 2.273 \\
\hline 9 & 0.44 & 2.275 \\
\hline 10 & 0.426 & 2.35 \\
\hline
\end{tabular}

\section{Story Displacement}

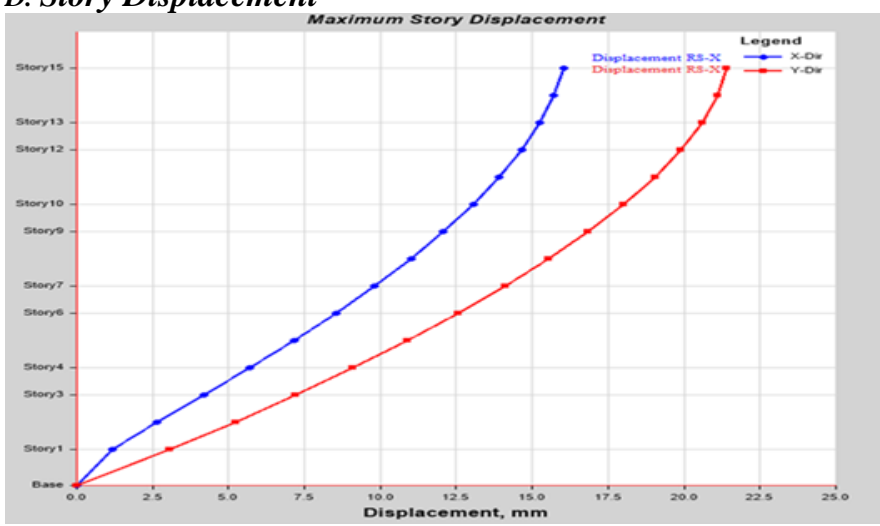

Figure 6 Maximum story displacement obtained from response spectrum in $\mathrm{X}$ direction

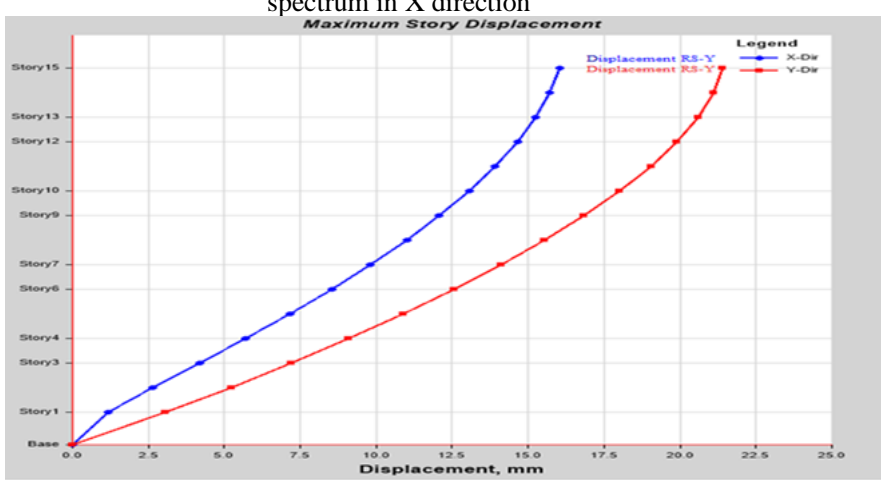

Figure 7 Maximum story displacement obtained from response spectrum in $\mathrm{Y}$ direction 


\section{E. Story Drift}

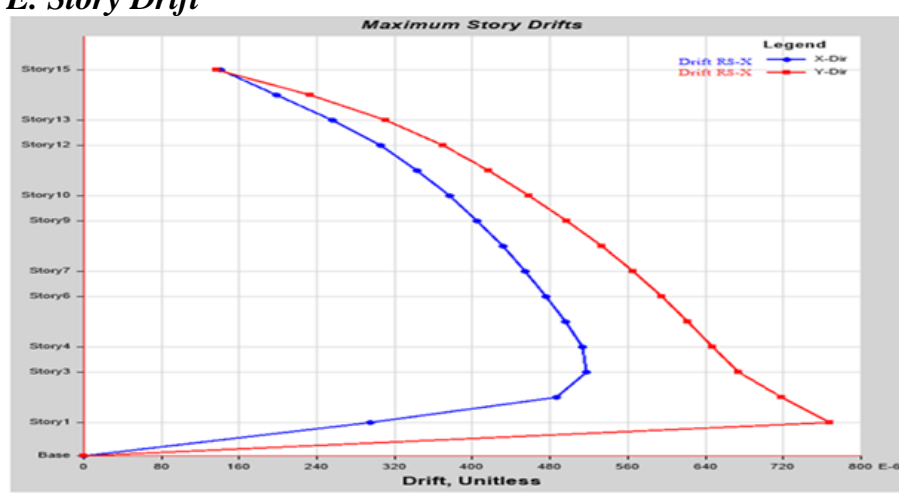

Figure 8 Maximum story drift obtained from response spectrum in $\mathrm{X}$ direction

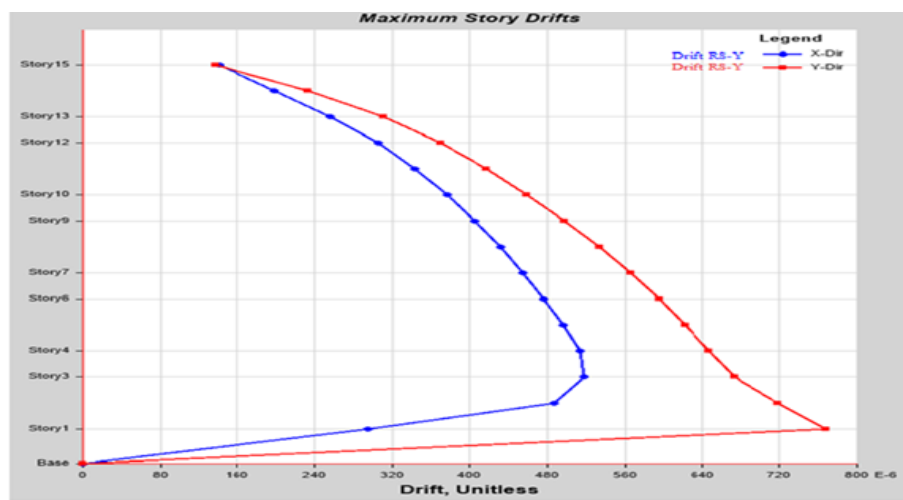

Figure 9 Maximum story drift obtained from response spectrum in $\mathrm{Y}$ direction

\section{F. Story Shear}

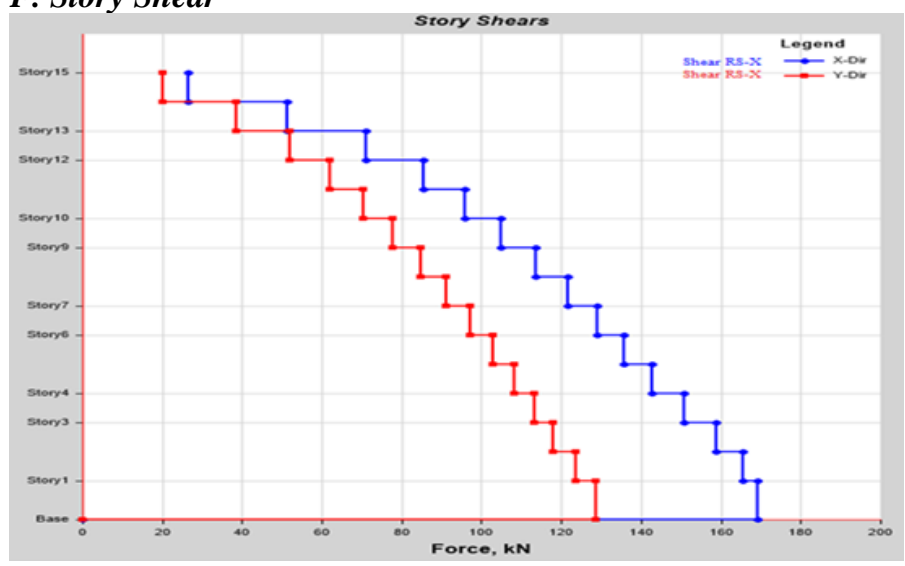

Figure 10 Maximum story shear obtained from response spectrum in $\mathrm{X}$ direction

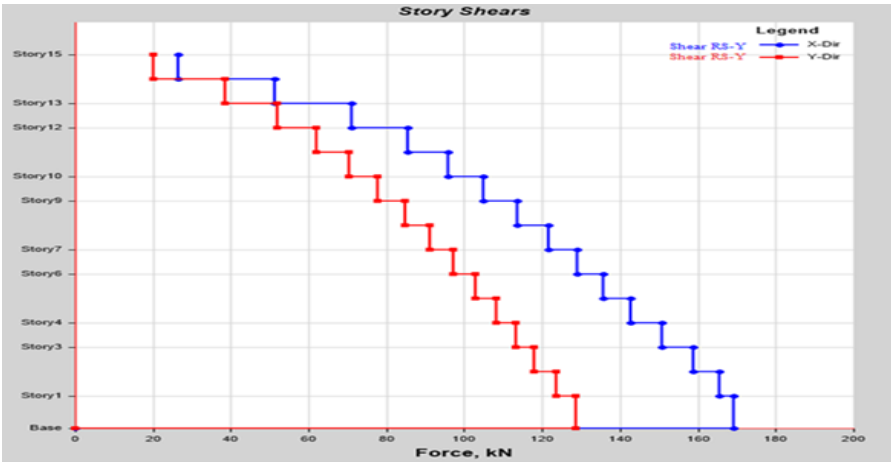

Figure 11 Maximum story shear obtained from response spectrum in Y direction

\section{CONCLUSIONS}

Based on the response spectra study on multi-story regular building, following points are concluded:

1. The dynamic analysis must be carried out for high rise structure with vertical regularities having height more than $40 \mathrm{~m}$.

2. As the modal mass participating factor is more than $75 \%$ in the higher mode, the considered structure is stiff for earthquake excitation.

3. Response spectrum analysis was performed on the building, from this analysis it was concluded that the structure has good resistance to smaller earthquake of moderate magnitude and intensity.

4. The story displacement in X-direction is found more as compared to $\mathrm{Y}$ and due to the fact that the earthquake motion was applied in $\mathrm{X}$-direction.

5. By the analysis results, we can find that the base reactions for the structure is coming little bit different from both the software's.

\section{REFERENCES}

[1] Vishal Sapate , Miss Diksha Kude, "Influence of Zone Factor on Seismic Performance of Multi-Storied RCC Frame using ETABS 2016", International Journal for Research in Applied Science \& Engineering Technology (IJRASET) Volume 8 Issue V May 2020.

[2] Nyein Thant, Tin Yadanar Kyaw, "Study on the Effect of Response Spectrum Analysis and Construction Sequence Analysis on Setback Steel Structure.”, International Journal of Trend in Scientific Research and Development, Volume-3 | Issue-4, June 2019 ..

[3] M V Naresh, K J Brahma Chari, "Study on Static and Dynamic Analysis of Multistorey Building in Seismic Zones." International Journal of Recent Technology and Engineering (IJRTE) Volume7, Issue-6C2, April 2019

[4] Sriskanthan Srisangeerthanan, M. Javad Hashemi, Pathmanathan Rajeev, Emad Gad, "Numerical study on the effects of diaphragm stiffness and strength on the seismic response of multi-story modular buildings.” Engineering Structures 163 (2018) 25-37

[5] Kiran Somasundar M, Rahul Leslie, Belarmin Xavier, "Study of comparison of applying nodes in response spectrum analysis." International Journal of Advanced Research in Engineering \& Management, Vol. 03-Issue 11 -2017-43-65

[6] M. Bello, A.A Adedeji, R.O. Rahmon, and M.A. Kamal, "Dynamic Analysis of Multi-Storey Building under Seismic Excitation by Response Spectrum Method using ETABS.” Journal of Research Information in Civil Engineering, Vol.14, No 4, 2017

[7] Ankit Purohit, Lovish Pamecha"Seismic Analysis of G+12 Multistory Building Varying Zone and Soil Type. "International Journal of Civil Engineering June 2017

[8] P. Rajeswari, Mr. A. Koti Neelakantam, "Seismic Analysis and design of multistory building in different seismic zones by using ETABS." International Research Journal of Engineering and Technology (IRJET) Volume: 06 Issue: 09 | Sep 2019

[9] Prateek Kumar, Jitendra Singh Yadav, "Result Analysis of Multistory Building by Using Response Spectrum Method for Floating Column." International Research Journal of Engineering and Technology (IRJET) Volume: 05 Issue: 11 | Nov 2018

[10] K. Harshavardhana Reddy, D. Mohammed Rafi, Dr. C. Ramachandrudu"Comparative Study on The Analysis Results of Multi-Story Commercial Building $(\mathrm{G}+12)$ by Using STAADPRO and ETABS". International Journal of Scientific Research in Science and Technology, Volume $6 \mid$ Issue $3 \mid 2019$.

[11] Prakriti Chandrakar, Dr. P. S. Bokare, "A Review - Comparison between Response Spectrum Method and Time History Method for Dynamic Analysis of Multistoried Building." International Journal of Science and Research (IJSR) Volume 6 Issue 5, May 2017 
[12] Khattab Saleem Abdul-Razzaq "Effect of seismic load of reinforced concrete multistory building from economical point of view." IJISET- International Journal of Civil Engineering \& Technology, November 2018.

[13] Suchi Nag Choudhary, Dr. P.S Bokare, "Dynamic Analysis of Multistory Building Using Response Spectrum Method and Seismic Coefficient Method." International Journal for Research in Applied Science \& Engineering Technology (IJRASET) Volume 7 Issue IV, Apr 2019

[14] Sugupta R. Amin, S.K. Mahajan, "Analysis of a Multistory RCC Building for Construction Sequence Loading”.

[15] Prashanth. P. Anshuman .S. Pandey. R.K. Arpan Herbert, "Comparison of design Results of a structure designed using STAADPRO \& ETABS software's". INTERNATIONAL JOURNAL OF CIVIL AND STRUCTURAL ENGINEERING Volume 2, No 3, 2012

[16] Juned Raheem, Dileshwar Rana, Prof. "Seismic Analysis of Vertical \& Regular Geometric Irregular RCC Framed Buildings."

[17] K.R, Bhavani Shankar, Rakshith Gowda . "Seismic Analysis for Comparison of Regular And Vertically irregular RC Building with soft storey at different levels". International Journal of Science and Research (IJSR) Volume 5 Issue 7, July 2016

[18] Nonika. N, Mrs. Gargi Danda De. "Comparsion on seismic Analysis of Regular and Vertical regular Multistoried Building "International Journal for Research in Applied Science \&Engineering Technology. Volume 3, Issue VII, July 2015

[19] Kumar, M. and V. G. Babu, "Comparative Study of Seismic Performance of Building Having Mass Vertical Irregularity at Different Floor Levels." International Journal of Science and Research (IJSR), Volume 5 Issue 1, January 2016,

[20] Bagheri, B., K. A. Nivedita, and E. S. Firoozabad "Comparative damage assessment of irregular building based on static and dynamic analysis." American Journal of Civil Engineering 2016

[21] Arvindreddy and F. R. J., "Seismic analysis of RC regular and irregular frame structures." International Research Journal of Engineering and Technology (IRJET) Volume: 02 Issue: 05 | Aug-2015

[22] Bagheri, B., E. S. Firoozabad, and M. Yahyaei, "Comparative Study of the Static and Dynamic Analysis of Multi-Story Irregular Building.'International Journal of Civil, Environmental, Structural, Construction and Architectural Engineering Vol:6, No:11, 2012 